\title{
Argumentação no Ensino de Ciências: Ponderações Analíticas a Luz da Teoria de Chaïm Perelman e Lucie Olbrechts-Tyteca
}

\section{Argumentation in Science Education: Analytical Considerations in the Light of Chaïm Perelman and Lucie Olbrechts-Tyteca's theory}

\author{
Gerlany de Fátima dos Santos Pereira ${ }^{[0]}$ Brasil \\ José Messildo Viana Nunes ${ }^{(1)}$ Brasil \\ Nadia Magalhães da Silva Freitas ${ }^{\text {Bi) }}$ Brasil
}

Este estudo teve como objetivo analisar um Debate sobre uma controvérsia sociocientífica, referente aos alimentos transgênicos. Trata-se de uma pesquisa-ação, de natureza qualitativa, realizada junto a licenciandos de Biologia. O enredo formativo desenvolvese a partir de um estudo de caso fictício, intitulado "O caso simulado do açaí transgênico na Amazônia”. Um conjunto de atividades suscitaram discussões e argumentações sobre o tema, levados ao Debate. Para análise e interpretação dos dados, utilizou-se como abordagem teórica a classificação dos argumentos segundo Perelman e OlbrechtsTyteca, precisamente quanto a três grandes classes, quais sejam: argumentos quaselógicos, argumentos baseados na estrutura do real e argumentos que fundamentam a estrutura do real. Em um plano complementar, classificamos os argumentos segundo diferentes dimensões argumentativas (científica, ambiental, social e econômica). Quanto aos resultados, em geral, podemos afirmar que os argumentos de autoridade apresentam relação quase que direta com a dimensão científica da argumentação, utilizados pelos apoiadores dos transgênicos. Já os argumentos pragmáticos foram mais utilizados pelos grupos contrários à introdução do açaí transgênico, buscando elucidar as consequências desfavoráveis decorrentes de tal empreendimento, inclusive em referência ao Princípio da Precaução e ao ambiente amazônico. A experiência propiciou aos futuros professores uma formação ambiental, que apresentou a possibilidade de abordagens complexas de objetos de estudo e de ensino, bem como chamou atenção para a necessidade de adoção de metodologias ativas de ensino, cuja centralidade está no sujeito aprendente, o que pode se constituir referência ao fazer docente.

Palavras-chave: Ensino de Ciências; Argumentação; Controvérsia sociocientífica; Chaïm Perelman e Lucie Olbrechts-Tyteca. 
This study intended to analyze a Debate about a socio-scientific controversy related to Genetically Modified (GM) foods. This is a qualitative research-action carried out with undergraduate students of biology. The formative scenario develops from a fictitious case study, entitled "The simulated case of GM açaí in the Amazon". A host of activities sparked discussions and arguments on the topic, all of which were brought to the Debate. For the analysis and interpretation of the data, the classification of arguments according to Perelman and Olbrechts-Tyteca was used as a theoretical approach, precisely in relation to three major classes, namely: quasi-logical arguments, arguments based on the structure of the real and arguments that underlie the structure of the real. In a complementary plan, we categorized the arguments according to different argumentative dimensions (scientific, environmental, social and economic). As for the results, in general, we can say that the arguments of authority are almost directly related to the scientific dimension of the argument used by supporters of GM foods. On the other hand, the pragmatic arguments were more used by groups opposed to the introduction of GM açaí, seeking to elucidate the unfavorable consequences resulting from enterprise, including - references to the Precautionary Principle and the Amazonian environment. The experience provided future teachers with an environmental training, which presented the possibility of complex approaches to objects of study and teaching, as well as drew attention to the need to adopt active teaching methodologies, whose centrality is in the learning subject, which can become a reference when teaching.

Keywords: Science education; Argumentation; Socio-scientific controversy; Chaïm Perelman and Lucie Olbrechts-Tyteca.

\section{Introdução}

Atualmente vivemos cercados por produtos da ciência e da tecnologia. Dessa forma, não se pode pensar em um Ensino de Ciências (EC) desvinculado das práticas sociais. Assim, [...] "a educação básica propõe formar para a cidadania de modo que cada pessoa possa atuar no mundo real e global" (Freitas, 2011, p. 229). Apesar de a ciência ser parte direta ou indireta do cotidiano das pessoas, nos ambientes escolares, poucas vezes os alunos são postos em situação de ensino e de aprendizagem que explorem as relações entre Ciência, Tecnologia e Sociedade (CTS).

Em função disso, [...] "a população está usufruindo os produtos da ciência e da tecnologia sem, muitas vezes, compreender seus prós e contras" (Freitas, 2011, p. 229). Os Alimentos Transgênicos (AT) são um exemplo disso, desse modo, cabe a escola assumir seu papel frente a formação de cidadãos críticos que possam discernir e fazer suas escolhas de forma consciente e coerente. Como o representante do saber científico na escola, é ao professor que cabe a escolha da forma de abordar e de gerenciar discussões sobre temas de natureza sociocientíficos controversos, como os AT.

Nesses termos, defende-se que a utilização das controvérsias sociocientíficas, (CSC) em aulas de Ciências, seria uma alternativa para a promoção de uma formação 
mais sensível às questões que envolvem as relações CTS. Isso porque, levaria à formação cidadã e à alfabetização científica, tão almejada no EC, visto que as CSC atendem a esses requisitos e se constituem estratégias de ensino inovadoras (Silva \& Gastal, 2011; Pavão, 2011; Freitas, 2011). Trabalhos como os de Galvão et al. (2011) e Reis (2004) apontam que a utilização das CSC possibilita o desenvolvimento cognitivo, social, político, moral e ético dos estudantes, contribuindo para a promoção de conhecimentos, capacidade de pensamento crítico, atitudes e valores que favorecem o envolvimento ativo e responsável dos cidadãos na evolução da vida em sociedade. Segundo os autores, os assuntos controversos ainda são pouco discutidos em sala de aula e merecem atenção, como é o caso dos AT.

Anuncia-se, então, o potencial educativo de discussão de questões sociocientíficas controversas em aulas de Ciências (Pavão, 2011; Marcelino \& Marques, 2018), mas estas atividades não fazem parte das práticas escolares, mesmo quando tais questões compreendem os conteúdos curriculares e os professores consideram a discussão sobre as mesmas importantes (Reis \& Galvão, 2009).

Muitas são as dificuldades apontadas pelos docentes para que esses temas não sejam abordados em sala de aulas de Ciências. Essas dizem respeito, notadamente, à formação inicial, posto que nas matrizes curriculares dos cursos de formação de professores de Ciências, predominam componentes curriculares que nem sempre conseguem atingir as especificidades exigidas, levando o professor a uma formação deficitária em muitos casos, sem competências acadêmicas que deem conta de trabalhar com essas temáticas na Educação Básica (Reis \& Galvão, 2009; Dionor et al., 2020).

Nesse sentido, Pavão (2011) defende que no ensino de Ciências é função do professor oportunizar seus alunos a se engajarem em práticas que favoreçam ações de busca de conhecimentos a partir do diálogo, da interação, do experimento, concomitante a conjecturas. Desse modo, pode-se fomentar discussões atuais em sala como anunciadas por Marcelino e Marques (2018) a respeito de alimentos transgênicos, que segundo eles é um tema pouco abordado em pesquisa da área, na formação inicial e nos livros de Ciências.

Na problemática que se configura, Reis e Galvão (2009) evidenciaram que a implementação de atividades de discussão sobre questões sociocientíficas controversas depende decisivamente das convicções do professor sobre a relevância educacional destas atividades, bem como os conhecimentos necessários para a sua concepção, gestão e avaliação. O referido estudo defende que tais atividades se habilitam como uma forma de preparar os alunos para uma participação ativa e informada na sociedade, o que coaduna diretamente com o entendimento que deduz que o ensino de Ciências necessita destes elementos para ser bem sucedido.

Os temas controversos na pesquisa de Silva e Carvalho (2009) se configuram como um importante contexto dos conteúdos estudados na escola básica. De acordo com os dados analisados, nesse estudo, grande parte dos professores de Física em formação que participaram do mesmo, apresenta algumas dificuldades em planejar e realizar 
atividades de ensino mais articuladas com temas de natureza controversa, como, por exemplo, a falta de tempo para planejar e desenvolver ações dessa natureza e a escassez de material didático que possa auxiliá-los no planejamento.

Para responder a essa demanda, Nuangchalerm (2009) afirma que as questões sociocientíficas devem compor os estudos do professor em formação. Corrobora com essa assertiva os relatos de Auler e Delizoicov (2006), ao destacarem o pouco conhecimento dos professoresem relação à abordagem CTS, evidenciando a necessidade de inclusão de temas CTS na formação inicial e continuada dos professores, para que estes possam contribuir mais adequadamente para melhorar e inovar o ensino das Ciências, com vistas a atender às necessidades de formação dos cidadãos reflexivos, críticos, responsáveis e éticos.

Nesse sentido, Santos et al. (2012) afirmam que para se ter um cenário nessa perspectiva, o professor deve apresentar formação ampla, postura aberta, disposição para ouvir os estudantes, domínio para gerenciar os debates, as análises e o tempo de aulas, pois, segundo os autores, estes fatores são imprescindíveis para mediar às interações em sala de aula. Além disso, Evagorou et al. (2014) ressaltam que problemas sociocientíficos são mal definidos e carregados de valores, invocando questões ecológicas, econômicas, morais, educacionais, culturais, religiosas e valores recreativos que são limitados por falta de conhecimento. Assim, pode-se destacar enquanto fatores que limitam o uso de questões sociocientíficas controversas: uma inadequada formação inicial de professores, a complexidade dos temas a serem tratados em sala de aula e a falta de recursos necessários para que tais temas sejam discutidos com clareza por alunos e professores.

Soma-se a isso, a necessidade de o professor gerenciar discussões na forma de argumentos para lidar com questões sociocientíficas controversas em sala de aula, o que pode envolver questões éticas ou morais (Braund et al., 2007). Desse modo, o professor deve estar atento que o argumento sobre questões controversas requer consciência da ciência subjacente e as várias posições morais e éticas tomadas por estudantes de diversas origens culturais (Braund et al., 2007). Assim,

A partir da compreensão do lugar da cultura científica no ensino de Ciências e o modo essencial como este se dá no aluno, resta-nos a discussão sobre quais aspectos o professor pode usar a seu favor na busca por introduzir o aluno no novo campo conceitual. [...] a argumentação tem um potencial epistêmico para essa tarefa. [...] dentre os objetivos de um ensino de Ciências pautado na dialogicidade e na argumentação podem ser destacados como principais: desenvolver nos estudantes o conhecimento e habilidades sobre a natureza da ciência; estimular a cidadania, particularmente no caso de questões sociocientíficas; e promover o mais alto grau de raciocínio, favorecendo a aprendizagem. Essa perspectiva corrobora ainda com o estabelecido pelos Parâmetros Curriculares Nacionais, que apontam como um dos principais objetivos da educação no Ensino Fundamental o desenvolvimento da capacidade de argumentação e tomada de decisão por parte dos alunos [...] (Oliveira, 2012, p. 27).

Portanto, observa-se a necessidade de ampliação de estudos que abordem assuntos controversos em aulas de Ciências, principalmente com enfoque na prática da argumentação suscitada por essa dinâmica de abordagem em sala de aula. Destaca-se 
os referentes aos temas biotecnológicos, entre os quais, os AT têm especial destaque. Há uma carência relatada sobre esse tema, assim anuncia-se uma problemática e justifica-se a inserção de questões sociocientíficas controversas nos cursos de formação inicial de professores, para que estes tenham suporte científico para trabalharem em sala de aula na educação básica.

Nesse contexto, discussões sobre temáticas biotecnológicas ainda são subvalorizadas, notadamente no EC, em termos de aprofundamento e de extensão merecida, o que reforça a necessidade de fomentar discussões nesse âmbito. Aliada às controvérsias, muito importante e pouco utilizada é a argumentação no EC. Tanto é, que nas [...] "duas últimas décadas, as pesquisas em Educação em Ciências vêm recomendando atenção às práticas argumentativas em sala de aula” (Bernardo, 2015, p. 1), ao considerá-la como indutora de processos formativos, capazes de desenvolver nos alunos especificidades que auxiliam no processo de formação cidadã.

Nesses termos, o presente trabalho tem na argumentação o objeto de investigação, compreendendo-a nos termos de Chaïm Perelman e Lucie Olbrechts-Tyteca, explicitado na seção que se segue. Objetivou-se com a pesquisa, analisar um Debate sobre uma controvérsia sociocientífica referente aos AT, realizado por um grupo de professores de Biologia em formação, segundo a Teoria de Argumentação de Chaïm Perelman e Lucie Olbrechts-Tyteca e, adicionalmente, segundo diferentes dimensões argumentativas (científica, ambiental, social e econômica), que constituem os argumentos.

\section{Teoria da argumentação à luz de Chaïm Perelman e Lucie Olbrechts-Tyteca: alguns apontamentos}

A teoria da argumentação, designada por Perelman (1993) como nova retórica (ou uma nova dialética), defende que todo o discurso que tenda a influenciar uma ou várias pessoas, a dirigir uma ação e que não busque validade formal, como no campo da lógica, compete ao ramo da retórica. Desde a antiguidade, essa prática de influenciar e convencer pessoas compõe um fenômeno social, cujas pessoas envolvidas são identificadas, conforme Perelman (1987, 1993) e Perelman e Olbrechts-Tyteca (2005), como auditório. Nesse sentido, a dinâmica de funcionamento do auditório gira em torno da adesão das pessoas a quem se dirige um discurso - "adesão dos espíritos”. Esse enredo leva à justaposição entre a teoria da argumentação e a retórica (Oléron, 1996; Perelman \& Olbrechts-Tyteca, 2005; Boavida, 2005).

Para Breton e Gauthier (2001), o desenvolvimento da teoria da argumentação vinculou-se ao da retórica aristotélica, desde a antiguidade até nossos dias. Com efeito, inspirou a cultura da argumentação que se desenvolveu no quadro da república e dos primeiros tempos do Império Romano e assistiu à sistematização, codificação e vulgarização das normas do discurso persuasivo por grandes oradores como Cícero e Quintiliano. Após a queda do Império Romano, a retórica foi progressivamente decaindo de importância e, mesmo sobrevivendo como prática, não era considerada enquanto objeto de estudo.

Os autores afirmam que a teoria argumentativa, do ponto de vista científico, perdeu 
credibilidade por se apoiar na retórica, visto que esta não é um método para produzir ideias ou opiniões, mas para defendê-las e lhes fornecer argumentos. Mesmo assim, a retórica se transformou em conteúdo de ensino, pois se apresentava como pertinente ao exercício acadêmico. No século XIX, assistiu-se ao decréscimo da influência da própria retórica, que acaba por ser excluída dos programas escolares. O seu desaparecimento arrastou consigo, mesmo que temporariamente, ao ostracismo todas as teorias da argumentação. Desse modo,

O movimento deste declínio do discurso argumentativo é duplo. Começa por ser interno: no seio da retórica, as duas fases que são a disposição e a elocução irão assumir progressivamente um papel crescente num domínio novo - a expressão literária. A seguir, é externa: a argumentação irá ser substituída pela demonstração racional, nomeadamente a partir de Descartes, privando a retórica de toda essa parte essencial que é a teoria da invenção (Breton \& Gauthier, 2001, p. 45-46).

Assim, a teoria argumentativa declinou no seio da retórica desde o final do Império Romano até meados do século XX. Nesse sentido, a retórica tornou-se uma teoria das figuras de estilo e a parte argumentativa reduziu-se à lógica, em decorrência do êxito crescente da demonstração matemática.

Para Plantin (2008), a obra publicada em francês, O Tratado da Argumentação, de Perelman e Olbrechts-Tyteca, em 1958, deu início ao movimento de renascimento, emancipação e refundação dos estudos sobre a argumentação. Paralelamente, também, em 1958, Toulmin deu sua contribuição para essa refundação, publicando em inglês, Os usos do argumento. Nesta pesquisa, ao referir-se às obras supracitadas, recorre-se às edições atuais de 2005 e 2006, respectivamente, já traduzidas para o português.

Com a recuperação da teoria da argumentação, consegue-se visualizar sua importância, apoiados em pressupostos filosóficos. Nesses termos, a teoria da argumentação concebida por Perelman (1993, p. 24),

[...] "diz respeito a aqueles discursos que se destinam a todos e quaisquer grupos de auditórios, que trate [...] de uma turma reunida na praça pública ou de uma reunião de especialistas, quer nos dirijamos a um único indivíduo ou a toda a humanidade; ela examinará mesmo os argumentos que dirigimos a nós mesmos a quando de uma deliberação íntima”.

Como objeto da teoria da argumentação, o estudo do discurso não demonstrativo, ou seja, a análise dos raciocínios que não se limitam a inferências formalmente corretas, a cálculos mais ou menos mecanizados, exclui-se do campo da argumentação, ou seja, tudo aquilo que não se insere no domínio do discurso, bem como aquilo que não é mediado pela linguagem natural e pelo raciocínio. É nesse sentido, que o Tratado de Argumentação versa apenas sobre os recursos discursivos para obter a adesão dos espíritos.

Perelman (1992) assegura que a lógica moderna não se ocupa senão das propriedades objetivas, como verdade, falsidade, probabilidade, necessidade, entre outras, independentes das atitudes dos homens e dos que eles pensam ou creem. $\mathrm{O}$ 
mesmo ocorre com os axiomas de um sistema, assim como as regras de substituição e dedução que indicam quais as operações permitidas, conforme as regras, é que permitirão distinguir uma dedução correta de uma incorreta (Perelman, 1992). Assim, na construção de um sistema axiomático atenta-se apenas a busca de consistência interna livre de contradições e ambiguidades; desta forma obtém-se demonstrações coercivas. Diferente da lógica formal que sustentam as demonstrações, a lógica informal justifica a ação, que permite resolver uma controvérsia, tomar uma decisão razoável, assim funciona a lógica da argumentação na busca de adesão dos espíritos (Perelman, 1992).

Segundo Perelman e Olbrechts-Tyteca (2005), os argumentos devem enfocar assuntos de interesse comum a um determinado auditório, as discussões geradas pela prática da argumentação giram em torno da defesa de pontos de vistas, por vezes divergentes. Nesse sentido, pode-se chegar a um acordo sem abandonar o campo da razão. No entanto, procura-se transcender as categorias da lógica formal, na utilização do raciocínio persuasivo e na argumentação justificada. Desse modo,

[...] querer convencer alguém implica sempre certa modéstia da parte de quem argumenta, o que ele diz não constitui uma 'palavra do Evangelho', ele não dispõe dessa autoridade que faz com que o que diz seja indiscutível e obtém imediatamente a convicção. Ele admite que deve persuadir, pensar nos argumentos que podem influenciar seu interlocutor, preocupar-se, interessar-se por seu estado de espírito (Perelman \& Olbrechts-Tyteca, 2005, p. 18).

Percebe-se o quanto é importante que o debatedor (aqui entendido como orador) esteja atento ao seu público (auditório) para melhor conquistar a sua adesão. Vale destacar, que Grácio (1993) ressalta que modernamente a posição do orador é relativa e pode ser assumida por qualquer membro de um auditório, ou seja, numa sala de aula que se implementa a prática da argumentação tem-se uma diversidade de oradores conforme buscam adesão a seus argumentos na defesa de pontos de vista, isto é, quem recebe a incumbência de defender, influenciar e convencer seus pares será o orador.

Nesses termos, considera-se que os aspectos até aqui abordados, relativos à Teoria da Argumentação de Perelman (como a importância da adesão dos espíritos, orador e auditório - para exemplificar), parecem fazer sentido, quando encontra aplicabilidade dos mesmos no campo educacional, mais precisamente para o EC. Nesse sentido, a tradição retórica - que por muitos séculos foi apoio do ensino - pode perfeitamente oferecer subsídios relevantes para ponderações sobre a prática educacional e para o EC.

Observa-se que nas ponderações concernentes à nova retórica - orador e auditório - há um enorme potencial para refletir a prática pedagógica de natureza dialógica, levando em consideração o educando como sujeito de saber, posto que argumentar é também ter apreço pelo interlocutor. Portanto, se a "regra de ouro" da Teoria da Argumentação é que o orador deve "amoldar-se" a seu auditório, por que não a expandir à sala de aula, à relação aluno-professor? Desse modo,

[...] a prática pedagógica e os processos de formação de professores não podem negligenciar quanto aos limites necessários ao estabelecimento do diálogo em sala de 
aula. Porém, disposição para ouvir é muito mais do que apenas escutar. É ter apreço pelo que o outro tem a dizer. Essa é a grande sintonia da teoria da argumentação com as pedagogias dialógicas: a realização da regra segundo a qual o orador deve partir do que é admitido pelo auditório enquanto valorização dos saberes prévios dos educandos (Lemgruber \& Rivelli, 2011, p. 8).

Considera-se, assim, que noções como "orador" e "auditório" podem ser favoráveis para balizar reflexões acerca das relações pedagógicas com base no diálogo de saberes. A intenção ao abordar tais aspectos (Teoria da Argumentação), no presente texto, foi de buscar estabelecer aproximações entre a "nova retórica" e o campo educacional, mais precisamente no EC, justificando-se a utilização e a consideração de alguns de seus aspectos, ao se trabalhar com as CSC.

\section{Referencial metodológico da investigação}

A presente pesquisa refere-se a uma abordagem qualitativa, no contexto de uma pesquisa-ação. No que diz respeito à pesquisa-ação, Barbier (2007, p. 53) menciona que esta tem por finalidade [...] "servir de instrumento de mudança social [...] a pesquisaação postula que não se pode dissociar a produção de conhecimentos dos esforços feitos para levar à mudança”. Fato é que esse tipo de pesquisa, além de buscar compreender, visa intervir na realidade, com vistas a modificá-la. O conhecimento almejado articulase a uma finalidade intencional de alteração da situação pesquisada. Dessa forma, ao mesmo tempo em que se realiza um diagnóstico e a análise de uma determinada questão, a pesquisa-ação propõe, ao conjunto de sujeitos envolvidos, mudanças que levam a um aprimoramento das práticas analisadas.

Este estudo foi realizado nas dependências de uma universidade pública brasileira, da região amazônica, junto a discentes da Licenciatura em Ciências Biológicas ${ }^{1}$, num contexto de um Curso de Extensão que discutia os AT, utilizando como estratégia de ensino o estudo de caso fictício intitulado "O caso simulado do açaí transgênico na Amazônia". Nesses termos, destaca-se que o [...] "método de Estudo de Casos é uma variante do método Aprendizado Baseado em Problemas ou Aprendizado Centrado em Problemas" (Sá \& Queiroz, 2010, p. 11). O estudo de caso representava uma CSC, uma vez que a aceitação dos AT polariza a sociedade e a própria comunidade científica, quanto a decisão de sua produção e, por desdobramento, sua comercialização e/ou consumo, em face das discussões dos aspectos éticos, políticos, sociais, econômicos e ambientais que suscitam os AT (Lacey, 2006).

O Curso de Extensão, balizado por um estudo de caso fictício, como referido, foi organizado em várias etapas, a saber: (1) apresentação das "Orientações gerais para o desenvolvimento do trabalho; (2) apresentação da "Controvérsia"; (3) apresentação da "Posição dos Grupos de Interesse na Controvérsia"; (3) apresentação das "Orientações gerais da dinâmica das atividades"; (4) orientações do "Trabalho das equipes e da distribuição das tarefas"; (5) Organização, por parte dos discentes, do "Plano de

1 Participaram do curso 25 alunos da Licenciatura em Ciências Biológicas da referida Universidade, os quais se voluntariaram e assinaram o Termo de Consentimento Livre e Esclarecido. 
Trabalho", para melhor desenvolvimento das atividades posta ao Curso e ao próprio desenvolvimento do caso; (6) orientações para "Elaboração do texto argumentativo", atividade prévia ao (6) "Debate", atividade finalística, juntamente com o (7) Parecer Decisório.

No processo formativo, propiciado pelo Curso de Extensão, os alunos foram instrumentalizados com artigos e capítulos de livros que versavam sobre a temática dos AT, nos seus diferentes domínios científicos, além de serem estimulados para a realização de pesquisas bibliográficas, que pudessem, adicionalmente, fundamentá-los na defesa dos argumentos, conforme sua participação em um ou outro grupo de interesse. O Curso ocorreu em 18 dias, com uma carga horária total de 100 h.

O enredo central do estudo de caso fictício, apresentado aos discentes, baseavase na proposta de um empreendimento multinacional que pretendia estabelecer-se no estado do Pará, com o objetivo de produzir açaí transgênico, resistente à antracnose, doença responsável por perdas na produção do açaí (fato real) (Embrapa, 2003; Reis, 2010), como solução para tal problema, se assim fosse decidido, no município (também fictício) de Igarapé Grande, estado do Pará. Nesse processo, constituíram-se quatro grupos de interesse (fictícios), propostos pelo caso, cuja integração dos alunos em um dado grupo de interesse ocorreu de forma aleatória (sorteio).

Além do grupo de interesse fictício, representado pela Empresa de Agronegócio e Biotecnologia (AGROBIO), que propôs a introdução do açaí transgênico na Amazônia, outros grupos de interesse se formaram, a saber: Empresa de Consultoria e Serviços Autônomos (ECTSA), Cooperativa de Produção Agrícola do Norte Paraense (COOPERNORTE), Instituto de Engenharia Genética (IEG), da Universidade Federal Paraense e o Movimento Não aos Transgênicos (MNT). Desses, dois eram favoráveis a introdução do açaí transgênico (AGROBIO e IEG) e dois outros contrários (MNT e COOPERNORTE), os quais se confrontariam na defesa dos seus argumentos, quanto a introdução ou não do açaí transgênico na Amazônia, precisamente em um Debate, uma das atividades finalísticas do Curso de Extensão. Um quinto grupo, a ECTSA, foi responsável por tomar a decisão de "resolução" da controvérsia, ao analisar os argumentos apresentados no Debate pelos grupos de interesse concorrentes.

Neste ponto, destaca-se que as duas atividades fundamentais ao Curso de Extensão, e ao próprio desenvolvimento do caso, constituíram-se do Debate e do Parecer Decisório. No Debate, com regras específicas ${ }^{2}$, os alunos apresentaram argumentos compatíveis com o que defendiam cada Grupo de Interesse - argumentos favoráveis ou contrários à introdução do açaí transgênico na Amazônia paraense (elementos

2 O debate foi organizado em três rodadas, com características específicas. Na primeira rodada, cada Grupo de Interesse apresentou seu ponto de vista balizado nos estudos e nas pesquisas realizados, no âmbito do Curso de Extensão. Na sequência, cada Grupo de Interesse apreciou a fala inicial de um dos seus oponentes (livre escolha), iniciando assim a discussão. O Grupo de Interesse citado teve direito a réplica, e foi concedida a tréplica ao Grupo de Interesse que apreciou a fala do seu oponente. Na segunda rodada, cada Grupo de Interesse entregou três perguntas, indicando o seu direcionamento. Os questionamentos, a cada Grupo de Interesse, foram respondidos. Foi permitida a réplica do Grupo de Interesse que formulou a pergunta e a tréplica do Grupo de Interesse questionado. $\mathrm{Na}$ terceira e última rodada, cada Grupo de Interesse se reuniu para elaborar mais uma pergunta, endereçada a qualquer outro grupo, de livre escolha. Por fim, cada Grupo de Interesse apresentou suas considerações finais. 
que serviram às análises aqui realizadas). No que concerne ao Parecer Decisório ${ }^{3}$, a equipe que representou a ECTSA, posteriormente ao debate, apresentou sua decisão, considerando as argumentações dos grupos de interesse (favoráveis e contrários), também considerados nas análises.

A escolha pelo Debate justifica-se por dar centralidade ao exercício da argumentação. Nesse sentido, Chiaro e Leitão (2005, p. 350) consideram o debate uma [...] "atividade social discursiva que se realiza pela justificação de pontos de vista e consideração de perspectivas contrárias (contra-argumento) com o objetivo último de promover mudanças nas representações dos participantes sobre o tema discutido". Ademais, o [...] "debate, como estratégia, provê um ambiente propício para que os alunos aprendam a argumentar, isto é, que se tornem capazes de reconhecer as afirmações contraditórias e aquelas que dão suporte às afirmações" (Altarugio et al. 2010, p. 28).

Duas perspectivas constituíram o quadro analítico. A primeira perspectiva de análise tem relação com a classificação desses argumentos, segundo a teoria da argumentação de Perelman e Olbrechts-Tyteca (2005), em três grandes classes de argumentos, a saber: argumentos quase-lógicos, argumentos baseados na estrutura do real e argumentos que fundamentam a estrutura do real. Esse referencial foi usado em virtude de apresentar um espectro abrangente para se compreender, agrupar e analisar os argumentos de acordo com suas classes, subclasses e tipos.

Apresentamos, em seguida, uma compreensão sucinta de cada classe e suas respectivas subclasses, assim como as técnicas argumentativas pertencentes as classes dos argumentos:

- Argumentos Quase-Lógicos - tratam de argumentos que [...] "têm pretensão a certa validade em virtude de seu aspecto racional, derivado da relação mais ou menos estreita existente entre eles e certas fórmulas lógicas ou matemáticas" (Perelman; Olbrechts-Tyteca, 2005, p. 297), por isso evocam os raciocínios formais, dedutivos, entretanto, pelo fato de utilizarem a linguagem natural, isto é, aquela empregada cotidianamente, são suscetíveis de interpretações diversificadas, o que não é possível com a linguagem formal que é homogênea. Essa classe de argumentos apresenta técnicas que a caracteriza, a saber: contradição e incompatibilidade; identidade e definição na argumentação; reciprocidade; transitividade; comparação; argumentos que relacionam o todo e as partes e argumentação pelo sacrifício e probabilidade. Como exemplo de argumento quaselógico de comparação, Oliveira (2012, p. 112) destaca que em sua pesquisa que:

A comparação também foi uma técnica argumentativa amplamente observada. Sendo, segundo classificação empreendida por Perelman e Olbrechts-Tyteca (2005), um argumento quase-lógico [...]. A comparação entre o retículo endoplasmático liso e

3 Texto geral constando de observações pertinentes a temática, contemplando neste os aspectos teóricos, conceituais e técnicos, entre outros. Nesse texto, ainda, constou de informações e argumentos (devidamente referenciados com os textos de apoio fornecidos e/ou aqueles frutos de pesquisas autônomas) que endossassem a decisão da controvérsia, e ao final do texto coube a indicação a decisão a respeito da controvérsia. 
as mitocôndrias, observada no $8^{\circ}$ ano, sugere que ambas são estruturas celulares de transformação.

- Argumentos Baseados na Estrutura do Real - existem [...] "diferentes tipos de argumentos, classificados conforme a estrutura do real às quais se aplicam e que podem ser encontrados no uso comum" (Perelman \& Olbrechts-Tyteca, 2005, p. 298). No entanto, o importante [...] "não é uma descrição objetiva do real, mas a maneira pela qual se apresentam as opiniões a ele concernentes, podendo estas, aliás, ser tratadas, quer como fatos, quer como verdades, quer como presunções" (Perelman \& Olbrechts-Tyteca, 2005, p. 298). Dessa forma, tratam de [...] "os argumentos que se aplicam a ligações de sucessão, que unem um fenômeno às suas consequências ou às suas causas, assim como os argumentos que se aplicam à ligações de coexistência" (Perelman \& Olbrechts-Tyteca, 2005, p. 298); assim, tem-se as subclasses argumentos de ligações de sucessão, com os seguintes tipos: argumentos de vínculo causal, argumentos pragmáticos, os fins e os meios e os argumentos de desperdício, da direção e da superação; ligações de coexistência, com os tipos: argumento da pessoa e seus atos, argumento de autoridade e as técnicas de ruptura e refreamento e as ligações simbólicas que congregam os tipos: argumentos hierárquicos e das diferenças de grau e ordem.

Em sua pesquisa, Sousa (2017, p. 63) evidenciou que grande parte dos argumentos, explicitados por alunos de uma turma de Licenciatura para os anos iniciais, eram do tipo argumento baseado na estrutura do real, como exemplo cita o tipo argumento pragmático, ao introduzir estudos sobre o funcionamento do coração: "A gente pegou um pedacinho da patinha (do camundongo formolizado) e do (músculo do) coração e fomos olhar na lupa, mas não dava para identificar".

- Argumentos que fundamentam a estrutura do real - divididos em duas subclasses os que fundamentam pelo caso particular, têm-se os tipos: a argumentação pelo exemplo, ilustração, modelo e por analogia. Nesse sentido, Silva Júnior (2019, p. 34) destaca como argumento por analogia que: "A sociedade precisa ser solidária como são os órgãos do corpo humano, pois o estômago precisa das mãos, da boca e dos dentes, assim como eles precisam daqueles".

De um modo geral, os trabalhos de pesquisa que versam sobre argumentação, tanto aqueles com alunos da escola básica quanto superior (licenciaturas) e, também, com professores, a exemplo de Sousa (2017) e de Silva Júnior (2019), as argumentações concentravam-se em algumas das classificações, com prevalência de uma ou duas componentes da grande classe de argumentos elencados por Perelman e OlbrechtsTyteca (2005).

A segunda perspectiva está relacionada com as dimensões nas quais os argumentos apresentados no Debate foram organizados, quais sejam: social, ambiental, científica, econômica. É nesse contexto, que se pode afirmar que a dimensão social da argumentação concerne aos argumentos que mencionam os aspectos da vida em sociedade, dentre eles 
o direito à vida, o direito de ser pessoa, à liberdade real, à igualdade de oportunidades, à moradia e à terra, ao trabalho em condições justas, de participar das riquezas, à educação, à saúde, de participar do governo, de receber os serviços públicos gratuitos e de qualidade, entre outros (Dallari, 2014).

Enquanto, a dimensão ambiental faz referência aos aspectos concernentes ao meio ambiente, entendido em seu aspecto natural, como aquele que abrange os atributos naturais que compõem nosso planeta. Segundo Buarque (2016, p. 1),

Estes atributos se identificam com a própria existência do ser humano, e são compostos pelo solo, pela água, ar atmosférico, flora e fauna e, por evidência, pelos elementos naturais que os integram. E nesta integração ocorre a correlação recíproca entre as espécies e as suas relações com o ambiente físico que ocupam.

Já a dimensão científica diz respeito a todos os aspectos que fazem alusão às pesquisas e aos pressupostos científicos, ao conjunto de conhecimento das mais diversas áreas do saber, que são baseados em comprovações ou teorias, que independente da área, tenha o conhecimento certificado, devendo apresentar-se os métodos específicos a fim de comprovar sua veracidade, bem como provas, por intermédio de um conjunto comumente denominado método científico (Lacey, 2008). E, por fim, a dimensão econômica está relacionada aos aspectos como renda, emprego, consumo, produção e comercialização, produção não apenas no sentido de "produzir um determinado produto", mas especificamente ao crescimento econômico. Está também relacionada à forma de organização do capital humano, financeiro, físico, da terra, e em como tudo isso é organizado para suprir as necessidades sociais (Rossetti, 2016).

Neste trabalho, a análise das duas perspectivas perscrutadas compreendeu as seguintes etapas: identificação, ponderação e interpretação de padrões surgentes. Esse tipo de análise colabora para a geração de uma análise interpretativa (Esteban, 2010), de modo que a busca por padrões entre, neste caso, as argumentações, configura-se como uma abordagem dedutiva, pois parte dos elementos contemplados nas duas perspectivas elencadas neste trabalho, sempre em interlocução com literatura pertinente do tema em estudo. Esses aspectos são características importantes de análises qualitativas (Minayo, 2016).

\section{Constructos argumentativos sobre a controvérsia sociocientífica do açaí transgênico na Amazônia paraense}

Alguns argumentos utilizados pelos grupos de interesse (favoráveis e contrários) foram analisados e aqui apresentados, precisamente aqueles plausíveis ("exemplares"), no nosso entendimento, ao seu enquadramento nas três grandes classes de argumentos, propostas pela teoria da argumentação de Perelman e Olbrechts-Tyteca (2005), bem como nas dimensões já indicadas anteriormente, de modo que a compreensão do processo analítico se mostrasse "útil" a novos empreendimentos analíticos, no campo da argumentação no EC. Vejamos, então, os posicionamentos iniciais, apreciação das falas de um dos oponentes, a réplica e a tréplica de cada uma das equipes, bem como seus 
argumentos na finalização do Debate; a análise dos argumentos do parecer decisório, que "solucionou" a controvérsia tratada, obedeceu aos mesmos critérios de análise dos grupos de interesse.

\section{AGROBIO: posicionamentos iniciais}

$\mathrm{Na}$ fala da AGROBIO, no que concerne às dimensões da argumentação, predominaram argumentos de dimensão ambiental, notadamente quando o grupo prestou esclarecimentos quanto ao uso de agrotóxicos, a saber: "A AGROBIO não vai empregar nenhum agrotóxico, nenhuma substância química no solo. A nossa modificação é apenas genética, somente na semente [...] a gente não vai tá influenciando diretamente o solo comprometendo-o de qualquer outra forma" (Sujeito A). O grupo busca convencer o auditório que sua forma de pensar - que tem por base pressupostos científicos, para exemplificar, os estudos de James (1998), que faz uma análise global das lavouras transgênicas comercializadas, e Paterniani (2009) que apresenta em sua obra as alterações genéticas nas plantas, ambas evidenciando a possibilidade de modificações genéticas nas sementes - é a que deve ser levada em consideração como correta.

Cumprindo, assim, o papel de orador empenhado no convencimento do auditório, de que as ações da AGROBIO não implicarão em medidas que possam ser prejudiciais ao solo, amparado na literatura científica. No que diz respeito à classificação do argumento utilizado pela AGROBIO, nos termos de Perelman e Olbrechts-Tyteca (2005), observou-se que este diz respeito a um argumento baseado na estrutura do real, no qual [...] "reside na característica de partirem de coisas reconhecidas para introduzir outras que se querem ver admitidas" (Grácio, 2015, p. 1), subclasse ligações de sucessão, [...] "estas, unem um fenômeno às suas consequências ou suas causas" (Perelman \& Olbrechts-Tyteca, 2005, p. 298), e tipo vínculo causal. Assim, quando a AGROBIO refere que não fará uso de agrotóxicos ou substâncias químicas no solo, e sim apenas modificações genéticas no açaí (semente), subentende-se o não comprometimento do solo (argumentado pela multinacional) é um efeito que deve resultar de um dado acontecimento, no caso, a modificação genética do açaí.

No excerto a seguir, observa-se argumentação de dimensão econômica quando o sujeito menciona que sem a utilização de agrotóxicos e pesticidas pela AGROBIO nas mudas de açaí transgênico: [...] "vai diminuir o custo de produção [...] vai aumentar a produtividade [...] você vai ter um lucro com isso" (Sujeito B). Assim, nos termos de Montella (2012), a melhora da produtividade poderá, consequentemente, ocasionar aumento nos lucros. Nesse contexto, trata-se de um argumento baseado na estrutura do real, subclasse ligações de sucessão, tipo vínculo causal, pois relacionam dois acontecimentos sucessivos dados entre eles (diminuição dos custos da produção e aumento da produtividade), por meio de um vínculo causal (lucro) (Perelman, \& Olbrechts-Tyteca, 2005).

Ainda, na fala do sujeito B, da AGROBIO, destacou-se argumentação de dimensão social, qual seja: [...] “a AGROBIO [...] não se preocupa apenas em fazer grãos [...] ela se 
preocupa com lado social, onde a gente se impõe, como é o caso aqui na região norte do Pará" (Sujeito B). A fala do sujeito em questão não é uma novidade no que diz respeito ao discurso incorporado por empresas multinacionais que se instalaram/instalam na região amazônica (Aguzzoli et al., 2006). Assim, concernente à classificação dos argumentos, nos termos de Perelman e Olbrechts-Tyteca (2005), trata-se daquele baseado na estrutura do real, subclasse ligações de sucessão, tipo fins e meios posto que alguns [...] "Alguns fins, parecem desejáveis, porque são criados ou tornados facilmente acessíveis" (Perelman \& Olbrechts-Tyteca, 2005, p. 312) - seria no caso, a consequente melhoria no lado social alegada pela AGROBIO - [...] "os meios de realizá-los" (Perelman \& Olbrechts-Tyteca, 2005, p. 312) - quando o sujeito, representante da empresa se refere à produção de grãos.

O seguinte argumento, pautado na dimensão científica é apresentado: [...] "haverá um fruto resistente ao fungo Colletotrichum gloeosporioides, causador da antracnose que é um grande vilão para os que vivem da cultura do açaí, onde os prejuízos são de grande impacto para esses produtores (Sujeito B). Nesse argumento, de dimensão científica, observa-se que o sujeito aborda a melhoria genética desse açaí transgênico na sua fala. Nota-se, portanto, a utilização de conhecimento científico específico por parte do sujeito, posto que sua argumentação apresenta sustentação na literatura, ou seja, a [...] "antracnose é uma das mais importantes doenças associadas a uma grande infinidade de cultivares em todo o mundo" (Reis, 2010, p. 4). Nos termos de Perelman e Olbrechts-Tyteca (2005), trata-se de um argumento baseado na estrutura do real, na subclasse ligações de sucessão, e tipo vínculo causal, pois segundo a empresa, haverá um fruto resistente ao fungo, e se este fungo é o vilão das plantações de açaí, logo, o fruto modificado geneticamente terá ação benéfica nas plantações, sendo este um efeito resultante deste acontecimento.

O sujeito B, encerra os primeiros momentos de fala da AGROBIO, apresentando várias dimensões argumentativas, a exemplo, da dimensão social: "Além desses benefícios, a AGROBIO procura melhorar a vida da população daquela região"; econômica: [...] "onde a mão de obra utilizada será em grande parte, de preferência daquela localidade, o que leva ao aumento de trabalhadores assalariados e com carteira assinada"; econômica: "Logo traz consigo um crescimento do comércio local, maior poder de compra dos moradores e um eventual crescimento social"; e social: "Uma marca de nossa empresa são os cursos profissionalizantes oferecidos onde nos instalamos [...]". Suas argumentações nos fazem pensar que se trata de dimensões indissociáveis, econômica/social; entretanto, o que se observa, na realidade, é que os processos de desenvolvimento estão apoiados, quase que exclusivamente na dimensão econômica, em detrimento da social e ambiental.

De um modo geral, na análise das argumentações, é válido considerar que o meio, no caso o grupo de interesse aqui representado pela AGROBIO, é quem circunscreve os argumentos e, de certa forma, é quem direciona as argumentações subsequentes, ou seja, dos demais grupos de interesse. O meio emana as categorias de argumentação. Os argumentos utilizados, por sua vez, vão ser, de certa maneira, moldados pelo ambiente. Então, no ambiente, pode-se perceber todo o sistema de classificação e 
mais, um delineamento de classificação que vem em determinado momento sendo majoritariamente de um tipo (no caso deste grupo, vínculo causal), depois de outro (no caso do IEG, argumento de autoridade, como será visto adiante).

\section{IEG: posicionamentos iniciais}

O representante do IEG inicia sua fala fazendo uso de um argumento baseado na estrutura do real, na subclasse Ligações de Coexistência, estas [...] "unem uma pessoa a seus atos, um grupo aos indivíduos que dele fazem parte e, em geral, uma essência a suas manifestações" (Perelman \& Olbrechts-Tyteca, 2005, p. 299), tipo de autoridade ao ter sua assertiva influenciada pelo prestígio de um célebre cientista, a saber:

[...] no ano de 1974, Paul Berg, um cientista muito renomado, disse a seguinte frase: "O uso da tecnologia [quando se referia aos transgênicos e a biotecnologia] apresenta vários riscos possíveis, alguns deles potencialmente perigosos, se não existirem os devidos controles". A partícula "se", abre muitas possibilidades para que nós possamos explorar essa tecnologia [...], não é à toa que no mundo inteiro, não só no Brasil, mas primeiramente em outroslugares, essa tecnologia, ela tem crescido bastante" [...] (Sujeito D).

No que diz respeito à dimensão, pode-se dizer que este argumento está inserido na dimensão científica, pois faz referência à utilização da tecnologia de transgenia e à biotecnologia, seus potenciais riscos e devidos controles e também seu crescimento. Essa é uma discussão ainda muito presente no meio científico e social. Observa-se na literatura estudos que trazem essa abordagem como de Borém e Carneiro (2008), Vinhas e Pereira (2016) entre outros, apontando calorosas discussões entre grupos contrários e favoráveis à biotecnologia, notadamente, aos transgênicos.

Sobre a classificação perelmeniana, que este argumento foi enquadrado, os autores afirmam que [...] "existe uma série de argumentos cujo alcance é totalmente condicionado pelo prestígio. A palavra honra, dada por alguém como uma prova de uma asserção, dependerá da opinião que se tem dessa pessoa como homem de honra" (Perelman \& Olbrechts-Tyteca, 2005, p. 347). Assim, ao se referir a um dos grandes nomes da Biotecnologia (Paul Berg), o sujeito está trazendo uma autoridade da área, uma pessoa de grande prestígio para sustentar sua fala.

Segue-se a exposição, na qual a dimensão ambiental é considerada:

[...] o Brasil, em 2008, foi um dos maiores consumidores de agrotóxicos. E isso devido às diversas pragas que atacaram muitas lavouras. É possível que através da técnica dos transgênicos nós possamos reduzir esse número, reduzir esse consumo de agrotóxico [...] que seja viável para esse açaí que vai ser implantado. (Sujeito D)

A fala do sujeito D encontra sustentação na literatura, inclusive com estudos bem mais atualizados (Almeida, Carneiro, 2010; Araújo, Oliveira, 2017) que corroboram diretamente com o argumento exposto. Quanto à classificação dos argumentos nos termos de Perelman e Olbrechts-Tyteca (2005), observou-se que estes dizem respeito a argumentos baseados na estrutura do real, na subclasse ligações de sucessão, tipo vínculo causal, já que "sendo dado um acontecimento" (o Brasil ser um dos maiores consumidores 
de agrotóxicos), "tende a descobrir a existência de uma causa que pode determiná-lo" (devido às diversas pragas que atacaram muitas lavouras), "tende a evidenciar o efeito que dele deve resultar" (através da técnica dos transgênicos possamos reduzir esse número, esse consumo de agrotóxico).

O sujeito E, apoia suas argumentações nas dimensões social (ao trazer a abordagem dos possíveis perigos ao corpo humano/saúde humana), explicitamente, e científica e ambiental, implicitamente, vejamos:

É fato que há hoje muitas discussões a respeito do perigo que os transgênicos podem fornecer ao corpo humano. Mas também é fato que hoje, estudos comprovam que os transgênicos não causam tantos impactos ou que os impactos que eles causam são mínimos quando comparados a lavouras não transgênicas. (Sujeito E)

De fato, os riscos que os AT podem trazer ao ser humano tem sido preocupação constante na literatura científica, como demonstram os estudos de Vasconcelos, Carneiro e Valicente (2011), configurando-se como dimensão social da argumentação, já que aborda aspectos relacionados à saúde humana. Ao mencionar que existem estudos que demonstram que os AT causam menos impactos que as lavouras não transgênicas, observam-se as dimensões científica e ambiental. Lacey (2006) aponta que segundo os defensores da transgenia, não [...] "há perigos para a saúde humana ou para o ambiente que se originem dos usos correntes e previstos das lavouras transgênicas e de seus produtos que representem riscos [...] que não possam ser adequadamente administrados por regulamentações responsavelmente planejadas" (p. 36).

Quanto à classificação dos argumentos nos termos de Perelman e OlbrechtsTyteca (2005), observou-se que tais argumentos dizem respeito ao argumento baseado na estrutura do real, na subclasse ligações de coexistência, tipo de autoridade, pois fazem menção a estudos científicos. Segundo os autores, os [...] "argumentos de autoridade [...] podem valer-se dos atos ou juízos de [...] um grupo de pessoas que tenham valor reconhecido, para que se obtenha um meio de prova a favor de uma tese" (Perelman, \& Olbrechts-Tyteca, 2005, p. 348).

O sujeito prossegue sua fala argumentando que além desses estudos, há diversos outros relacionados à alimentação, e faz alusão a ajuda que esses AT podem fornecer na alimentação mundial:

[...] como, por exemplo, o arroz dourado [...]. Esse arroz vem para suprir uma necessidade nutricional [em relação à] vitamina A. Esse arroz, ele é transgênico, ele vem com um diferencial, um novo gene que foi inserido nele, permite ele produzir o betacaroteno, que é o precursor da vitamina A [...] evitando doenças, como a cegueira noturna [...]. (Sujeito E)

A exposição do sujeito $\mathrm{E}$ apresenta fundamentação científica trazendo as dimensões científica e social da argumentação. Nesse sentido, a literatura aponta que as experiências com fortificação de alimentos evidenciam resultados satisfatórios na prevenção da deficiência de Vitamina A (DVA), na Ásia e América Central (Diniz; Santos, 2000). O avanço de técnicas de bioengenharia traz novas perspectivas no combate à 
DVA, como, por exemplo, o desenvolvimento do arroz geneticamente modificado com betacaroteno (Paine et al., 2005), o que coaduna, nesses aspectos, com o argumento apresentado pelo grupo.

Sobre a classificação dos argumentos, nos termos de Perelman e OlbrechtsTyteca (2005), trata-se de um argumento baseado na estrutura do real, na subclasse ligações de sucessão, tipo vínculo causal. Como nesse meio (ou grupo de interesse, no caso, IEG) foram apresentados argumentos de autoridade, então, emanavam de lá, do meio acadêmico, sendo perfeitamente justificável sua utilização, já que se trata de um grupo que representava um instituto de pesquisa científica de uma universidade fictícia.

\section{MNT: posicionamentos iniciais}

O grupo Movimento Não aos Transgênicos (MNT), contrário à introdução do açaí transgênico em terras paraenses, inicia sua exposição enfatizando que não existem resultados conclusivos para o caso do açaí transgênico, em específico. O sujeito $G$ é categórico ao afirmar:

[...] não podemos correr o risco de liberar a produção do açaí transgênico, o plantio, sem ter resultados conclusivos e com pesquisas em longo prazo [...]. Se ainda não existem estudos conclusivos que possam dar a certeza da segurança para a população de que o açaí transgênico não vai afetar nem a população, nem a biodiversidade local, nem os próprios produtores do local [...], por exemplo, através de fluxo gênico entre as populações do açaí. Então nós pedimos que não seja liberada a produção do açaí, enquanto não tivermos estudos que sejam realmente conclusivos em longo prazo para ver se há riscos ou não. (Sujeito $G$ )

Nesse excerto, apresentam-se as dimensões científica, ambiental e social da argumentação. Observa-se uma preocupação do grupo com a não liberação da produção, comercialização e do consumo de açaí transgênico, tanto por questões ambientais (provavelmente em referência ao fluxo gênico, como será visto a seguir) quanto por questões sociais (possíveis riscos à saúde humana). E tudo isso permeado pelo fato de o grupo demonstrar que essa preocupação tem relação com a não publicação de estudos que comprovem que, de fato, o açaí transgênico não traz danos à saúde e ao meio ambiente, especificamente, àquela região, denotando a natureza científica da argumentação.

Quanto à classificação no que concerne à Perelman e Olbrechts-Tyteca (2005), observou-se que se trata de um argumento baseado na estrutura do real, na subclasse ligações de sucessão, tipo pragmático, levando-se em consideração que este tipo de argumentação [...] "consiste em avaliar algo em função das consequências" (Grácio, 2015, p. 2). Assim, o grupo ponderou sobre os possíveis riscos da liberação do açaí transgênico na Amazônia paraense, no que tange aos possíveis prejuízos ao meio ambiente e à saúde das pessoas.

O sujeito $\mathrm{H}$, buscou apoiar a fala da colega de grupo, e seguiu sua linha de pensamento, ou seja, contrária aos alimentos transgênicos:

[...] A biotecnologia é uma tecnologia nova baseada em riscos e incertezas, 
insuficientemente conhecidos ou esclarecidos. As muitas incertezas giram em torno dos riscos envolvidos no seu processo de produção, plantio e consumo de alimentos transgênicos. Como riscos para a saúde humana com a possível toxidade, capacidade para induzir reações alérgicas e a possibilidade de transferência de resistência a antibióticos, além dos eventuais efeitos em longo prazo que venha a se manifestar, pois como a transgenia confere outras características, em geral, pouco avaliadas quanto aos seus impactos, ainda não foi gerada uma base de conhecimentos suficientes e adequados para saber os reais riscos envolvidos com o uso dos transgênicos. (Sujeito $\mathrm{H}$ )

Observa-se a consideração das dimensões científica (ao se mencionar a biotecnologia e a transgenia) e social (quando o sujeito refere os riscos à saúde humana). Diferente do sujeito $\mathrm{G}$, o sujeito $\mathrm{H}$ cita quais seriam esses riscos. De fato, esses riscos são muito discutidos na literatura (Lacey, 2006). Mas também existe uma série de estudos apresentados, a exemplo de Vasconcelos et al. (2011), que já apresentam resultados positivos sobre os alimentos geneticamente modificados. Em contrapartida, Ferment et al. (2015) trouxeram em sua obra mais de 750 estudos, alguns destes, com resultados não tão animadores para os defensores dos transgênicos.

No que tange à classificação de Perelman e Olbrechts-Tyteca (2005), observouse que se trata de um argumento baseado na estrutura do real, na subclasse ligações de sucessão, tipo pragmático. Vale novamente mencionar, que esse tipo de argumentação [...] "permite apreciar uma coisa consoante suas consequências, presentes ou futuras, tem uma importância direta para a ação" (Perelman \& Olbrechts-Tyteca, 2005, p. 303).

Continuando sua linha de pensamento, o sujeito $\mathrm{H}$ faz referência à dimensão ambiental, nos seguintes termos: [...] "o risco para o meio ambiente e a biodiversidade é extremamente alto com a perda da diversidade genética, a erosão genética, a poluição genética, surgimento de superpragas. Tudo isso por causa do risco de ocorrência do fluxo gênico". De acordo com Ferment et al. (2015), o fluxo gênico diz respeito a qualquer movimento de genes de uma população para a outra e inclui vários tipos de eventos diferentes. Sobre a impossibilidade de coexistência, os autores afirmam:

Fluxo gênico por fecundação cruzada (polinização), dispersão de sementes ou ainda transferência horizontal de genes (THG) em cultivos subsequentes a cultivos geneticamente modificados (GM) representam fatores naturais, fora do controle do agricultor e das empresas de biotecnologia, que impossibilitam a coexistência no campo das plantas GM e não GM. (Ferment et al., 2015, p. 168)

Assim, pode-se afirmar que a preocupação do grupo com a possibilidade do fluxo gênico, não é um fator que deva ser desconsiderado, uma vez que a literatura apresenta posicionamentos variados sobre a questão. Segundo a classificação de Perelman e Olbrechts-Tyteca (2005), observou-se que se trata de um argumento baseado na estrutura do real, subclasse ligações de sucessão, tipo pragmático, considerando-se que uma característica marcante desse sujeito é avaliar algo (implantação do açaí transgênico), em função de suas consequências desfavoráveis (perda da diversidade genética, a erosão genética, a poluição genética, surgimento de superpragas, consequências advindas do 
fluxo gênico).

$\mathrm{Na}$ conclusão de sua fala, o sujeito $\mathrm{H}$ apresenta mais uma vez as dimensões econômica e ambiental da argumentação: "Existem outras opções para se atingir a produtividade e solucionar problemas na produção do açaí, como a produção de uma agricultura sustentável, baseada na agroecologia, com a preocupação ambiental, segurança alimentar e melhoria da renda dos agricultores" [...]. De fato, ao mencionar a agroecologia, de certa forma, o argumento utilizado pelo sujeito $\mathrm{H}$ faz sentido, ao analisarse a literatura, posto como coloca alguns autores como Maghari e Ardekani (2011), Zdziarski, Carman e Haynes (2014), de que uma realidade oposta àquela prometida pelo setor da biotecnologia, suavizando e relativizando os supostos benefícios dessas tecnologias, sobre todas as dimensões referidas. A literatura destaca a superioridade do melhoramento convencional e dos sistemas de base agroecológica (Ferment et al., 2015).

Observou-se que nesse grupo de interesse, houve predominância de utilização dos argumentos pragmáticos, por se tratar de um grupo contrário, no que concerne à questão dos transgênicos. Pode-se inferir que provavelmente resida nesse fato sua intensa utilização, pois esse tipo de argumentação, como fora anteriormente evidenciado [...] "permite apreciar um ato ou um acontecimento consoante suas consequências favoráveis ou desfavoráveis" (Perelman \& Olbrechts-Tyteca, 2005, p. 303), desempenhando papel essencial na argumentação. Assim, diante da necessidade de destacar argumentações com as possíveis consequências desfavoráveis com a utilização dos transgênicos, o grupo tomou posse desse tipo de argumentos.

\section{COOPERNORTE: posicionamentos iniciais}

O último grupo a fazer suas considerações iniciais foi a COOPERNORTE, que apresenta posicionamento contrário à implantação do açaí transgênico na Amazônia Paraense, fato observado na fala do Sujeito I.

A COOPERNORTE posiciona-se contra a implantação da produção do açaí transgênico [...], pois acreditamos que essa produção acarretará em sérios impactos nos aspectos econômicos, sociais e, principalmente, ambientais. Alegamos que o açaí transgênico poderá causar danos à saúde humana e para a saúde dos animais que consomem o fruto do açaí, que pode provocar, nos humanos, alergias e o aparecimento de doenças ainda não conhecidas, assim como ocorreu com a soja e o milho também transgênicos. (Sujeito I)

Muito bem destacadas na fala do sujeito I, estão às dimensões econômica, social e ambiental. Ao mencionar alergias e o surgimento de doenças desconhecidas nos seres humanos e nos demais animais, que porventura venham a consumir esse açaí transgênico, uma preocupação que há muito tempo vem intrigando muitos pesquisadores e se fazendo bastante presente na literatura, como remete Ferment et al. (2015), que no meio de tanta polêmica em relação aos riscos para a saúde humana [...] "ainda não há consenso na comunidade científica sobre possibilidades de danos e limites aceitáveis de consumo, para alimentos compostos por plantas geneticamente modificadas e suas 
partes" (p. 275).

Assim, essa falta de consenso presente na literatura científica sobre o uso dos transgênicos e seus possíveis riscos à saúde humana, de certa forma, valida a argumentação utilizada pelo grupo em questão, no que concerne às preocupações expostas pela COOPERNORTE. Assim, no que diz respeito à classificação de Perelman e OlbrechtsTyteca (2005), nota-se que se trata de um argumento baseado na estrutura do real, na subclasse ligações de sucessão, tipo pragmático, pois as consequências desfavoráveis na visão do grupo são postas em destaque.

Prosseguindo com sua fala, o sujeito I volta a mencionar a dimensão ambiental, que vem sendo alvo de grande preocupação dos grupos contrários à introdução do açaí transgênico na Amazônia paraense, vejamos:

Também acreditamos que a produção do açaí transgênico possa trazer consequências negativas para o meio ambiente, pois um dos maiores perigos apontados quantos aos seres transgênicos se refere à possibilidade de haver o cruzamento entre cultivos transgênicos e não transgênicos, principalmente através da polinização. (Sujeito I)

Como Ferment et al., (2015) reportam, o cruzamento entre cultivares transgênicos e não transgênicos não é algo descartado. Assim, a possibilidade e/ou capacidade de o transgene [...] "inserido em determinado organismo vir a escapar daquele genoma, deslocando-se para o meio ambiente e afetando outros organismos ali estabelecidos, constitui importante fonte de incertezas e riscos" (Ferment et al., 2015, p. 89). Tal escape é possível mediante [...] "Transferência Vertical (TVG) ou Horizontal (THG) de Genes. No primeiro caso, o escape ocorre pelo cruzamento sexual entre organismos geneticamente aparentados (via de regra, de uma mesma espécie)" (Ferment et al., 2015, p. 89). Quanto à classificação de Perelman e Olbrechts-Tyteca (2005), novamente, foi feito uso de argumento baseado na estrutura do real, na subclasse ligações de sucessão, tipo pragmático, pelo fato de ter sido dado destaque às avaliações desfavoráveis do grupo (cruzamento entre cultivos transgênicos e não transgênicos), diante da possibilidade da implantação do açaí transgênico).

A COOPERNORTE encerra sua apresentação inicial, trazendo as dimensões científica e ambiental da argumentação:

Porém, segundo Hicks e Alyub, estudos realizados com soja, outro produto modificado geneticamente [...] mostram resultados que após o período de redução da quantidade de agroquímicos utilizados, nos quatro anos seguintes, a quantidade aumentou gradativamente em função de que a cada safra a quantidade de herbicida deveria ser aumentada para surtir o efeito desejado. E isso aconteceu em função de ervas daninhas adquirirem resistência ao produto utilizado, fazendo-se necessário o aumento do uso de agrotóxico. (Sujeito I)

$\mathrm{Na}$ literatura observam-se muitos estudos relativos aos impactos negativos específicos dos principais herbicidas associados ao cultivo de plantas geneticamente modificadas, como os de Modesto e Martinez (2010) e Cuhra, Traavik e Bøhn (2013), conferindo validade à argumentação utilizada pelo grupo em questão. No que concerne 
à classificação dos argumentos nos termos de Perelman e Olbrechts-Tyteca (2005), podese afirmar que se trata de um argumento baseado na estrutura do real, subclasse Ligações de Coexistência, tipo de autoridade, por fazerem referência a pesquisadores que segundo o grupo, são autoridades na área, tomando o prestígio de pesquisador como "palavra de honra". Contudo, devido suas peculiaridades de apreciação de um acontecimento diante de suas consequências desfavoráveis apontada pelo sujeito em destaque (aumento gradativo da quantidade de agroquímicos no estudo em questão), pode-se afirmar que se trata também de um argumento baseado na estrutura do real, subclasse ligações de sucessão, tipo pragmático.

Observou-se que o presente grupo de interesse, assim como o anterior (que apresenta posicionamento contrário aos transgênicos), apesar de ter feito uso de argumentos de autoridade, apropriou-se predominantemente em suas falas, dos argumentos pragmáticos, segundo a classificação perelmaniana. Possivelmente pelo mesmo motivo que o grupo anterior (MNT), qual seja: se tratar de um grupo contrário no que concerne ao tema dos transgênicos, que busca evidenciar as consequências negativas da utilização de OGM para a sociedade.

\section{Ponderações gerais sobre os posicionamentos iniciais no debate}

Todos os grupos apreciaram a exposições dos demais grupos de interesse, apresentando réplicas e tréplicas no debate. Percebeu-se, que os sujeitos de pesquisa buscaram a base de suas argumentações em artigos, publicações em periódicos específicos e em cientistas de renomes para justificar suas argumentações. $\mathrm{O}$ direcionamento do aprendizado via argumentação, pauta-se por uma formação cidadã, aquela que está além dos conteúdos ministrados em sala de aula, aquela que instiga o aluno a construir conhecimentos, e não apenas entrar em contato com os conhecimentos "prontos e acabados". Assim, possibilitou-se aos discentes participantes a construção do seu próprio universo de significação, relativo à apreensão crítica da realidade em uma perspectiva ampla, com inserção em diferentes campos societários (social, ambiental, econômico, entre outros), dinâmica que pode reverberar no ambiente de sala de aula desses futuros professores, ao vivenciarem que um dado objeto de estudo e de ensino, deve ser considerado a partir de suas múltiplas dimensões.

A AGROBIO apresentou em suas argumentações, quanto à classificação perelmaniana, com predominância da subclasse ligações de sucessão, tipo vínculo causal, embora outros tipos como fins e meios e argumentos pragmáticos tenham surgido ao longo das análises. Em uma breve avaliação das dimensões, pode-se avaliar que a dimensão social foi a mais presente nas argumentações do grupo, embora as dimensões ambiental e econômica tenham tido bastante destaque ao longo do Debate. É válido considerar que no caso da AGROBIO, não se pode vincular uma dimensão diretamente a uma classe ou tipo de argumento, mas pode-se complementar o sentido da argumentação, com a sua classificação nos termos de Perelman e Olbrechts-Tyteca.

Já o IEG mostrou, predominantemente, no que diz respeito à classificação 
das argumentações, uso da subclasse ligações de coexistência, tipo autoridade. As argumentações do grupo vincularam-se a outras classificações como "vínculo causal" e "pragmático", mas procurou sustentáculo na literatura científica, recorrendo, essencialmente, às dimensões científica e social da argumentação, embora tenham feito uso de outras dimensões, como a ambiental. Aqui, pode-se fazer uma relação muito mais próxima do tipo de argumento predominante (argumentos de autoridade) com a dimensão argumentativa predominante (científica), o que denota uma forte característica do grupo, por se tratar de pessoas que representaram um instituto de pesquisa de uma universidade (mesmo que fictícia).

Quanto ao MNT e COOPERNORTE, pode-se observar que foram grupos que utilizaram, predominantemente, quanto à classificação perelmeniana, a subclasse ligações de coexistência, tipo argumento pragmático. Os grupos buscaram evidenciar as consequências desfavoráveis à utilização de transgênicos e, apesar disso, trouxeram outros tipos de argumentos para suas falas, como é o caso dos argumentos de autoridade. Não houve uma dimensão argumentativa predominante nos argumentos utilizados pelos dois grupos. As suas falas foram bem diversificadas e trouxeram múltiplas dimensões para o Debate.

\section{Encerrando o debate}

A AGROBIO utilizou seu tempo para reafirmar alguns aspectos, direcionando sua fala aos outros grupos de interesse. Assim, para a COOPERNORTE, esclareceu que "para o açaí transgênico, nós não usamos vetor algum. Nós apenas cortamos as enzimas de restrição, cola com o DNA ligase" (Sujeito C). Em sua argumentação o sujeito C faz uso da dimensão científica. Ao mencionar a não utilização de vetores na "construção" do açaí transgênico, e sim enzimas de restrição, também denominadas endonucleases, que são enzimas que cortam a molécula de DNA por meio do reconhecimento de sequências nucleotídicas específicas. É patente que o sujeito menciona conhecimento específico da técnica, embora não o aprofunde em sua argumentação. $\mathrm{O}$ sujeito $\mathrm{C}$ segue sua fala, direcionando agora a sua argumentação para o MNT.

[...] nossa coleta permanecerá sendo tradicional, coleta manual, portanto, não haverá necessidade de desmatar para abrir vias ou desmatar para criar novas estradas para o escoamento. As vias de escoamento serão as mesmas já utilizadas pela COOPERNORTE. O fato de aqui na Amazônia já haver a maior produção de açaí, acho que isso significa um risco para AGROBIO. Afinal de contas, ter a maior produção significa também ter um grande mercado e um mercado seguro. Portanto, nós que somos novos nada vai garantir pra gente que a gente vai ter um mercado também aqui. (Sujeito C)

Nessa fala, observa-se a utilização das dimensões ambiental e econômica da argumentação. Menciona-se a questão da coleta, que segundo a AGROBIO permanecerá ocorrendo da forma tradicional, o que justifica a não necessidade do desmatamento para ocorrer o escoamento da produção do fruto, deixando clara a dimensão ambiental do argumento. Ao mencionar "um risco para AGROBIO", pode-se pensar que a multinacional 
ao adentrar num mercado novo, trazendo um produto novo - açaí transgênico - em face da polêmica que ainda tem se estabelecido em torno dos transgênicos e, ainda, da grande produção deste fruto nos moldes tradicionais, há que se pensar nos riscos econômicos deste empreendimento.

Observa-se a utilização de argumento baseado na estrutura do real, na subclasse ligações de sucessão, tipo pragmático, tendo em vista que a argumentação utilizada pela AGROBIO, visa dar destaque a uma avaliação em função de suas consequências (a coleta sendo tradicional, implica na não necessidade de desmatamento - favorável à população; o fato de já haver maior produção tradicional de açaí na Amazônia, significa um risco alegado para a AGROBIO - desfavorável à multinacional).

$\mathrm{O}$ MNT destaca em suas considerações, argumentos que concernem à dimensão social da argumentação, destacando a necessidade de esclarecimentos à população dos riscos à saúde humana. Observe-se: [...] "nós não podemos partir do princípio de que a população por ser uma população [que desconhece os aspectos científicos] não precisa ser esclarecida dos riscos que a implicação da semente transgênica poderá causar [riscos a saúde]" (Sujeito S). Nesse sentido, destaca-se que ao pressionar à AGROBIO sobre o esclarecimento dos riscos à saúde humana da inserção dos transgênicos naquele ambiente, o MNT faz uso de argumento baseado na estrutura do real, na subclasse ligações de sucessão, tipo pragmático, ao serem pensados, por eles, as possíveis consequências desfavoráveis ao uso dos transgênicos pela população.

Nas considerações finais do Instituto de Engenharia Genética, o grupo apresentou as dimensões social (saúde humana) e científica da argumentação.

Para começar falar sobre a saúde humana [...] uma coisa que a gente pode assegurar, quais os problemas que acontecem em relação à saúde humana? É o fato de um DNA exógeno, ou seja, de outro lugar, de um transgênico, seja adquirido por uma bactéria, e a bactéria se tornar super-resistente. Acontece que o gene que a gente tá usando é de uma planta comestível, o inhame. Então é um genoma que as pessoas consomem, e ele não tem essa relação de deixar a bactéria resistente. É comestível. Então essa é a vantagem. Então não tem previsão de trazer riscos para saúde, nesse sentido do consumo. A questão é o mecanismo de resistência que acontece. [...]. É o mecanismo de resistência morfológico que vai ser passado através da sequência genética do inhame para a do açaí. (Sujeito D)

O representante do Instituto volta a afirmar que se trata de algo que as pessoas já consomem, alegando que o gene que a AGROBIO está usando é de uma planta comestível, o inhame, assegurando que por esse motivo, que o mesmo não traz riscos à saúde humana. A dimensão científica é evidenciada ao se falar de DNA exógeno, superresistência de bactérias, genoma, termos que são próprios da linguagem científica/ acadêmica. Ressalta-se, de forma geral, que nos termos de Perelman e Olbrechts-Tyteca (2005), trata-se de argumento baseado na estrutura do real, subclasse ligações de sucessão, tipo vínculo causal, posto que o grupo assegura que, já que o gene presente no inhame é consumido pelas pessoas, logo, a extração desse gene via engenharia genética (técnica 
da transgenia) e sua implantação no açaí, consequentemente, não causará danos à saúde humana, percebendo-se uma relação causal no argumento.

Encerrando as argumentações do grupo, observa-se o emprego da dimensão científica da argumentação, ao mencionar as especificidades da técnica de transgenia, propriamente dita:

Outra coisa que eu queria esclarecer é quanto o uso do vetor para a COOPERNORTE. Gente! Existem dois métodos básicos para se transferir genes para dentro de uma planta. O primeiro mais utilizado é por meio de um plasmídeo, de uma bactéria. O plasmídeo de uma bactéria, ele não é o genoma [...] principal. O plasmídeo geralmente dá resistência a bactérias [...]. A bactéria que utilizada, a Agrobacterium tumefaciens, ela causa um tumor nas plantas. Mas você retira dela um plasmídeo e retira desses plasmídeos a parte que causa tumor na planta. Então quando você insere esse plasmídeo junto com a sua sequência desejada, ele não causa o tumor na planta porque a parte que causa o tumor você retirou, entendeu? É por isso que atualmente a mais usada é esse tipo de vetor, o plasmídeo dessa bactéria, que não é tóxico, que não causa danos a planta, porque a parte do genoma dele que iria causar dano, você já retirou, entendeu? E a segunda técnica é a biobalística que nós vamos usar agora, que não existe vetor, não tem plasmídeo, não tem vírus, não tem nada que você injete lá. Você apenas atira na planta um projétil. Um projétil com um revólver. E esse projétil, pode ser de ouro, de tungstênio, ele é revestido como um DNA desejado. Quando esse projétil atinge a célula, esse DNA migra em direção ao núcleo. Então não tem vetor. E essa técnica é altamente segura, altamente segura, tá? (Sujeito E)

Nos termos de Perelman e Olbrechts-Tyteca (2005), pode-se afiançar que se trata de um argumento baseado na estrutura do real, subclasse ligações de coexistência, tipo autoridade, por apresentar a fala sustentada na literatura científica, como foi praxe do grupo, ao longo de praticamente todo o Debate. Nas suas apreciações finais, os integrantes da COOPERNORTE buscam desqualificar os argumentos utilizados pelos grupos proponentes aos transgênicos, em especial a AGROBIO. Observe-se:

Já que o pessoal da AGROBIO e o pessoal do IEG não conhecem os riscos da transferência genômica do inhame para o açaí, a gente vai dizer alguns. Embora haja precisão no isolamento do gene, não há possibilidade de controlar a integração do inserto no genoma. E como consequência, poderá ocorrer a interrupção da expressão gênica de um gene da planta e do inserto se integrar no referido loco. Ou ainda a inserção do gene transferido poderá ocorrer em uma região rica em heterocromatina, onde a expressão gênica poderá ser reduzida ou insignificante, ou seja, não vai acontecer nada. Além disso, uma vez inserido a nova sequência poderá ser alvo de metilação, e a consequente inativação em termos de transcrição. Outra vez o gene pode ser silenciado, ou ocorrer a interferência de outro gene ou inserção. Isto está em um artigo brasileiro do ano de 1999. (Sujeito N)

Note-se, que o componente do grupo realizou busca por material acadêmico que conferisse suporte a sua fala, trazendo termos técnicos e próprios da linguagem científica, demonstrando conhecimento específico da temática em questão, o que leva 
a classificar esse argumento, nos termos de Perelman e Olbrechts-Tyteca (2005), como um argumento baseado na estrutura do real, subclasse ligações de coexistência, tipo de autoridade.

ECTSA apresenta seu parecer final, quanto apoiar ou não a introdução do açaí transgênico, nos seguintes termos:

A ECTSA manifesta-se contrária [...] pelos motivos listados abaixo: a empresa AGROBIO não leva em consideração os riscos, alegando que são inexistentes. Porém, eles existem. Ninguém, nem mesmo o mais vociferante proponente duvida que certos usos dos transgênicos podem envolver riscos para a saúde e o meio ambiente. Qualquer inovação tecnocientífica, ainda que ligada à pesquisa e ao desenvolvimento, envolve riscos. Os riscos à saúde humana incluem aqueles inesperados como alergias, toxicidade, intolerância. No ambiente, as consequências são a transferência lateral de genes, a poluição genética e os efeitos prejudiciais à organismos não alvo. Socialmente, a empresa criará um monopólio comercial, livre de concorrência e excludente, o que, de fato, prejudicará a principal fonte de renda do setor [comunidade].

$\mathrm{Na}$ argumentação da ECTSA, nota-se o destaque dado às dimensões social (saúde, monopólio comercial, com reflexo na fonte de renda da comunidade) e ambiental (transferência lateral de genes, poluição genética, efeitos negativos em organismos não alvos). A ECTSA alega que a AGROBIO "não leva em consideração os riscos, alegando que são inexistentes". Observa-se na literatura a existência de estudos que apontam os riscos ambientais e relacionados à saúde, envolvendo transgênicos, como já mencionado aqui. Entretanto, os grupos oponentes à introdução do açaí transgênico não apontam estudos relacionados diretamente ao açaí. Mas tem validade o fato deles alegarem que a AGROBIO não leva em consideração a existência de riscos sociais, ambientais e também econômicos.

E quando a ECTSA fala de riscos econômicos, entende-se que se trata de um argumento que procede. Imaginem uma situação hipotética de adesão dos produtores às sementes transgênicas de açaí, poderia sim se instalar um monopólio e a "perda" da cultura local em termos de produção de açaí nativo, o que é plausível ao se pensar na possibilidade de expansão do empreendimento. Assim sendo, na classificação Perelman e Olbrechts-Tyteca (2005), tem-se a utilização de argumento baseado na estrutura do real, na subclasse ligações de sucessão, tipo pragmático, tendo em vista que a argumentação utilizada pela ECTSA consistiu em [...] "apreciar um ato ou um acontecimento (aprovação da introdução do açaí transgênico pela AGROBIO) consoante suas consequências [...] desfavoráveis" (consistentes com os riscos ambientais, sociais e econômicos advindos desta aprovação) (Perelman \& Olbrechts-Tyteca, 2005, p. 303).

A ECTSA apresenta várias justificativas ao seu Parecer desfavorável, destaca-se uma delas, precisamente um dos aspectos do Princípio da Precaução, a saber: [...] "Os direitos daqueles que são afetados por uma atividade devem ser priorizados, e não os daqueles que são beneficiados por tal atividade". Nessa argumentação, empregada como justificativa ao seu Parecer, observa-se a utilização quanto à classificação de Perelman e 
Olbrechts-Tyteca (2005) de argumento baseado na estrutura do real, na subclasse ligações de coexistência, tipo de autoridade, pois se apropria de uma ideia que surgiu ainda na Antiguidade da humanidade:

O princípio da precaução foi formulado pelos gregos e significa ter cuidado e estar ciente. Precaução relaciona-se com a associação respeitosa e funcional do homem com a natureza. Trata das ações antecipatórias para proteger a saúde das pessoas e dos ecossistemas. Precaução é um dos princípios que guia as atividades humanas e incorpora parte de outros conceitos como justiça, equidade, respeito, senso comum e prevenção. (Ministério do Meio Ambiente, 2019, p. 1)

Cabe destacar, neste ponto, que o Princípio da Precaução não deve ser considerado como um empecilho a qualquer atividade, mas sim como um modo de proteger os autênticos interesses da sociedade. O Princípio da Precaução é uma abordagem importante às questões como, por exemplo, AT, notadamente ao se reconhecer as possibilidades de riscos potenciais à saúde humana e ao meio ambiente. É interessante notar, que no decorrer do Debate, a classificação nos termos de Perelman e OlbrechtsTyteca (2005) foi bem diversificada, com predominância em determinados momentos, de um tipo ou de outro de argumentos. Talvez porque os grupos já estivessem mais familiarizados com o ambiente de debate, bem como com os conteúdos mobilizados. Há de se levar em consideração que os grupos estavam bem preparados e, de maneira geral, apresentaram argumentações válidas para a controvérsia em questão.

Mas é interessante ressaltar, que os argumentos classificados como argumentos de autoridade, apresentam relação quase que direta com a dimensão científica da argumentação, o que faz bastante sentido, devido ao fato de que ao se mencionar estudos e utilizar dados científicos, nos quais são citadas pessoas, instituições e periódicos científicos, o que, no caso fictício, foram utilizados amplamente pelos grupos apoiadores dos transgênicos (IEG e AGROBIO). Já os argumentos pragmáticos foram mais utilizados pelos grupos contrários à introdução do açaí transgênico (COOPERNORTE e MNT), buscando elucidar as consequências desfavoráveis decorrentes de tal empreendimento.

\section{Conclusões e Implicações}

Pensar em constituir um cidadão cientificamente alfabetizado não parece ser uma tarefa tão simples, pois a sociedade atual exige que se forme não apenas sujeitos com vistas à resolução de problemas matemáticos ou que sejam capazes de compreender os problemas do mundo atual. Mais do que isso, o cidadão do século XXI necessita conhecer, saber lidar com possíveis problemáticas que envolvam o cotidiano, nos seus aspectos culturais, políticos, sociais, ambientais, econômicos, científicos, entre outros. Em termos gerais, pode-se ponderar que tais aspectos materializaram-se no Debate, que envolveu uma controvérsia sociocientífica, ao considerarmos os elementos argumentativos trazidos ao evento e aqui apresentados.

No decorrer deste estudo, a classificação dos argumentos dos grupos de interesse da controvérsia permitiu evidenciar que a prática da argumentação foi instituída, 
agregando e articulando conhecimentos de natureza diversa (científicos, ambientais, econômicos, sociais etc.), esquivando-se de considerações simplistas e simplificadores da situação, bem como de senso comum. Ao contrário, os discentes, futuros professores, empenharam-se nos estudos a respeito do tema, trazendo conhecimentos cientificamente balizados para o Debate, de modo que se propiciou uma ambiência estimuladora do aprendizado e, decerto, de uma postura futura significativa ao fazer docente.

Os sujeitos de pesquisa, futuros professores de Biologia, não se ativeram, unicamente, aos materiais a eles fornecidos, foram eles próprios buscar suas fontes de evidências, ou seja, periódicos de renome como a Revista Nature. Além disso, outras fontes trazidas pelos discentes apoiaram-se, sobremaneira, nos argumentos de autoridade, ao referir pesquisadores como Paul Berg e o European Journal of Entomology, para evidenciar resultados de estudos, dos quais eles citaram trechos inteiros ao longo do Debate, caracterizando-se como busca autônoma de conhecimentos.

Depreende-se, que esses sujeitos se apropriaram, com qualidade, dos aspectos relacionados ao AT, em vários campos de estudos. Assim, considera-se que a proposição de uma CSC possibilitou aos discentes analisar aspectos como os econômicos, sociais, culturais e científicos, relacionados aos AT, os quais foram contemplados nos argumentos elaborados, o que favoreceu, consequentemente, a problematização do cenário que envolve os AT, principalmente na consideração do ambiente amazônico.

Cabe destacar, neste ponto, que a literatura (Reis \& Galvão, 2009; Silva; Carvalho, 2009; Silva \& Gastal, 2011; Pavão, 2011; Freitas, 2011; Evagorou et al., 2014; Marcelino, \& Marques, 2018) aponta que os assuntos controversos raramente estão presentes nas salas de aulas de Ciências no Brasil, embora com grande potencial educativo; assim, as questões sociocientíficas controversas não são práticas usuais nas escolas em geral. Os empecilhos anunciados nas pesquisas abordadas neste artigo, apontam para dificuldades de os professores em planejar, realizar e mediar atividades relacionadas à temas de natureza controversa, muitas vezes em decorrência da complexidade dos temas. Esse panorama é decorrente, de acordo com os estudos, de uma formação inicial de professores de Ciências que não propicia esse tipo de prática/atividade. Esses aspectos, entre outros, são corroborados em trabalho recente de revisão de literatura (Dionor; Conrado et al., 2020).

Entende-se que esta pesquisa possibilitou que professores em formação inicial de Biologia se engajassem em práticas que favoreceram a busca autônoma de conhecimentos, de comunicação de ideias de forma dialogada, interativa e com confronto de argumentos sustentados por um processo de estudo científico. Dessa forma, os futuros docentes vislumbraram possibilidades de oportunizar a seus futuros alunos um ambiente de estudos e de discussões sobre questões sociocientíficas controversas, mediado por um estudo de caso, cujo aspecto de destaque referiu-se ao Debate. Ademais, o debate fez emergir algumas competências dos discentes, referentes ao planejamento, à articulação e à organização dos argumentos, por exemplo. Decerto, constituindo-se experiências necessárias aos discentes para lidar com essa prática e torná-la exequível em suas ações 
docentes futuras.

De um modo geral, a proposição de um estudo de caso, na formação inicial de professores, envolvendo uma CSC, com foco central na argumentação, representou, no conjunto, estratégia de ensino capaz de instrumentalizar futuros professores para o pensar, o interagir, o argumentar e o agir, em um contexto de formação fundamentado em estudos autodirigidos, favorecendo o posicionamento qualificado dos discentes, em um cenário de participação e engajamento na defesa e na tomada de decisão frente a questão posta, consoante com processos de alfabetização científica e de formação para a cidadania. Nesse sentido, os argumentos postos pela Teoria de Argumentação de Chaïm Perelman e Lucie Olbrechts-Tyteca foram evocados. Ademais, essa vivência, certamente, chamou atenção de futuros professores para a necessidade de uma abordagem complexa dos objetos de estudo e de ensino, bem como para a necessidade de adoção de metodologias de ensino e de aprendizagem que tenha centralidade no sujeito aprendente, a exemplo do estudo de caso, o qual estimula os alunos a busca autônoma de conhecimentos.

Ademais, pondera-se que uma autêntica CSC, no/para o contexto do EC, evoca, na sua discussão e decisão, argumentos que adentram o campo do pensamento complexo, no sentido de fazer emergir a multidimensionalidade e multirreferencialidade do objeto de/em estudo. Assim, ao se considerar a perspectiva de Chaïm Perelman e Lucie Olbrechts-Tyteca, foi possível evidenciar que os argumentos apresentados pelos discentes destacaram-se, sobremodo, pela natureza de autoridade, em uma relação concreta com a dimensão científica, exigida na discussão sobre o AT, afastando-se de uma abordagem ingênua, acrítica. Por sua vez, quando os aspectos de caráter deletério ao ser humano e ao ambiente (dimensão social e ambiental) foram evocados no Debate, emergem os argumentos pragmáticos, em vinculação ao princípio da precaução. Esse design de classificação permite avaliar a qualidade da argumentação das CSC no/para o EC, ao caracterizar sua natureza, para além de abordagens que desprezam elementos necessários ao entendimento amplo do problema

Para reflexão final e encaminhamentos de futuros estudos, destaca-se a necessidade de aprofundar discussões e pesquisas sobre a proposição de agregar o quadro teórico de Perelman e Olbrechts-Tyteca como uma aporte metodológico para a análise dos processos argumentativos no ensino de ciências, principalmente na consideração das dimensões social, ambiental, científica, econômica e outras que possam surgir, com intuito de se aditar as características e caracterizações dos argumentos as especificidades das atividades sociocientíficas controversas, conferindo um caráter aberto na abordagem dos temas que envolvem as CSC. Destaca-se que a complexidade em gerir situações, como a aqui apresentada, requer do professor saberes específicos do campo da argumentação, da área científica, ambiental e social, entre outros, que articulados permitem construir compreensões complexas de temas de natureza sociocientífica controversa. Tais condições só serão asseguradas mediante experiências contínuas dessa natureza, na formação inicial de professores, correspondendo a uma formação ambiental, de modo que as mesmas façam parte do repertório de possibilidades de ação docente. 


\section{Referências}

Aguzzoli, R. L., Aramburú, J. V., Doval, J. L. M., \& Antune, E. D. (2006). Capacitar para desenvolver: Como multinacionais estrangeiras no Brasil investem em sua mão-deobra? In Anais eletrônicos do 30 ENANPAD. Salvador-BA.

Almeida, V. E. S. de, \& Carneiro, F. (2010). Brasil é o país que mais usa agrotóxicos no mundo. Ecodebate Cidadania e Meio Ambiente. http://www.ecodebate.com. br/2010/07/08/brasil-e-o-pais-que-mais-usa-agrotoxicosno-mundo-artigo-defernando-ferreira-carneiro-e-vicente-eduardo-soares-e-almeida.

Araújo, I. M. M., \& Oliveira, A. G. R. C. (2017). Agronegócio e agrotóxicos: Impactos à saúde dos trabalhadores agrícolas no nordeste brasileiro. Revista Trabalho, Educação e Saúde, 15(1), 117-129. http://dx.doi.org/10.1590/1981-7746-sol00043

Barbier, R. (2007). A pesquisa-ação. Liber Livro Editora.

Bernardo, J. R. R. (2015). Argumentação no ensino de ciências: Tendências, práticas e metodologia de análise. Ens. Pesqui. Educ. Ciênc, Belo Horizonte, 17(1), 277-280. http:// dx.doi.org/10.1590/1983-211720175170113

Braund, M., Scholtz, Z., Lubben, F., \& Sadeck, M. (2007). Comparing the effect of scientific and socio-scientific argumentation tasks: Lessons from South Africa. School Science Review, Hatfield, 88(324), p. 67-76.

Breton. P., \& Gauthier G. (2001). História das Teorias da Argumentação. Trad. Carvalho, M. Bizâncio.

Boavida, A. M. R. (2005). A argumentação em matemática investigando o trabalho de duas professoras em contexto de colaboração. Tese (Doutorado em Educação). Faculdade de Ciências da Universidade de Lisboa, Departamento de Educação. Lisboa.

Borém, A., \& Carneiro, J. E. S. Fluxo gênico. (2008). In A, Borém, \& M. Del Giúdice (Orgs.), Biotecnologia e Meio Ambiente (pp. 405-420). Editora UFV.

Breton. P., \& Gauthier G. (2001). História das Teorias da Argumentação. Trad. Carvalho, M. (157 p). Bizâncio.

Buarque, S. H. (2016). Aspectos do meio ambiente. https://monitordigital.com.br/ aspectos-do-meio-ambiente.

Chiaro, S., \& Leitão, S. (2005). O papel do professor na construção discursiva da argumentação em sala de aula. Psicologia: Reflexão e Crítica, 18(3), 350-357. https:// dx.doi.org/10.1590/S0102-79722005000300009

Cuhra, M., Traavik, T., \& Bøhn, T. (2013). Clone-and age-dependent toxicity of a glyphosate commercial formulation and its active ingredient in Daphnia magna. Ecotoxicology, Switzerland, 22(2), 251-262. https://dx.doi.org/10.1007/s10646-0121021-1 
Dallari, D. A. (2014). Viver em sociedade. 2. ed. Prospectiva. https://www.aacademica. org/otavioluizmachado/54.pdf

Diniz, A. S., \& Santos, L. M. P. (2000). Hipovitaminose A e xeroftalmia. J. Pediatr, 76(Supl 3), 311-22.

Dionor, G. A., Conrado, D. M., Martins, L., \& Nunes Neto, N. de F. (2020). Análise de propostas de ensino baseadas em QSC: Uma revisão da literatura na educação básica. Alexandria: Revista de Educação em Ciência e Tecnologia,13(1), 197-224. https://dx.doi. org/10.5007/1982-5153.2020v13n1p197

Empresa Brasileira de Pesquisa Agropecuária (EMBRAPA). (2003) Práticas de conservação do solo e recuperação de áreas degradadas. EMBRAPA-Acre, https://www. infoteca.cnptia.embrapa.br/bitstream/doc/498802/1/doc90.pdf

Esteban, M. S. (2010). Pesquisa qualitativa em educação: Fundamentos e tradição. Artmed.

Evagorou, M., Guven, D., \& Mugaloglu, E. (2014). Preparing Elementary and Secondary Pre-Service Teachers for Everyday Science. Science Education International, 25(1), p. 68-78.

Ferment, G., Melgarejo, L., Fernandes, G. B., \& Ferraz, J. M. (2015). Lavouras transgênicas - riscos e incertezas: Mais de 750 estudos desprezados pelos órgãos reguladores de OGMs. Ministério do Desenvolvimento Agrário.

Freitas, D. (2011). A perspectiva curricular Ciência, Tecnologia e Sociedade - CTS - no ensino de Ciência. In A. C. Pavão, \& D. Freitas (Orgs.), Quanta ciência há no ensino de Ciências? (pp. 229-237). EdUFSCar.

Galvão, C., Reis, P., \& Freire, S. (2011). A discussão de controvérsias sociocientíficas na formação de professores. Ciência \& Educação, Bauru, 17(3), 505-522, https://dx.doi. org/10.1590/S1516-73132011000300001

Grácio, R. A. (2015). Auditório universal: Vocabulário de argumentação. http://www. ruigracio.com/VCA/AuditorioUniversal.htm.

Grácio, R. A. (1993). Introdução à tradução portuguesa da obra de Chaïm Perelman. $O$ império retórico: Retórica e argumentação, (pp. 5-11). Edições ASA.

James, C. (1998). Global status and distribution of comercial trangenic crops in. Biotecnology and Development Monitor, (35), 9-12. http://www.biotech-monitor. $\mathrm{nl} / 3504 . \mathrm{htm}$

Lacey, H. (2006). A controvérsia sobre os transgênicos: Questões científicas e éticas. 1 ed. Ideias e Letras.

Lacey, H. (2008). Ciência, respeito à natureza e bem-estar humano. Sci. stud. 6(3), 297327. http://dx.doi.org/10.1590/S1678-31662008000300002 
Lemgruber, M. S., \& Rivelli, H. (2011). Nova retórica e ensino de Ciências: uma interseção nas analogias. Educação e Cultura Contemporânea, 8(17), 1-19. http://periodicos.estacio. br/index.php/reeduc/article/view/175/129

Maghari, B., \& Ardekani, A. (2011). Genetically modified foods and social concerns. Avicenna JournalofMedicalBiotechnology, 3(3), 109-117.http://dx.doi.org/10.1590/198321172018200110

Marcelino, L. V., \& Marques, C. A. (2018). Controvérsias sobre os transgênicos nas compreensões de professores de Química. Revista Ensaio, 20, e9253, 1-21, https:// dx.doi.org/10.1590/1983-21172018200110

Minayo, M. C. de. S. (2016). Trabalho de campo: contexto de observação, interação e descoberta. In Minayo, M. C. de. S. (Org.), Delandes, S. F., \& Gomes, R. Pesquisa social: teoria, método e criatividade (pp.56-71). Vozes.

Ministério do Meio Ambiente. (2019). Princípio da Precaução. http://www.mma.gov.br/ clima/protecao-da-camada-de-ozonio/item/7512

Modesto, K., \& Martinez, C. (2010). Roundup ${ }^{\circledR}$ causes oxidative stress in liver and inhibits acetylcholinesterase in muscle and brain of the fish Prochilodus lineatus. Chemosphere, Amsterdã, 78(3), 294-299. https://dx.doi.org/10.1016/j.chemosphere.2009.10.047

Montella, M. (2012). Micro e macroeconomia. 2. ed. Atlas.

Oléron, P. L’argumentation. (1996). Presses Universitaires de France.

Oliveira, H. R. (2012). Argumentação no Ensino de Clências: o uso de analogias como recurso para a construção do conhecimento. (Dissertação de Mestrado). Programa de Pós-Graduação em Educação da Universidade Federal de Juiz de For a, MG.

Paine, J., Shipton, C. A., Chaggar, S., Howells, R. M., Kennedy, M. J., Vernon, G., Drake, R. (2005). Improving the nutritional value of Golden Rice through increased pro-vitamin A content. Nat Biotechnol, United Kingdom, 23(4), 482-7. http://dx.doi.org/10.1038/ nbt1082

Paterniani, M. L. S. (2009). Culturas transgênicas e a conservação da biodiversidade. In Carpentieri-Pípolo, V. (Org.). Culturas transgênicas: uma abordagem de benefícios e riscos. EDUEL, 131-152.

Pavão, A. C. (2011). Ensinar ciências fazendo ciência. In Pavão, A. C., Freitas, D. (Orgs.). Quanta ciência há no ensino de Ciências? EDdUFSCar. p. 15-23.

Perelman, C. (1987). Argumentação. In Enciclopédia Einaudi. Imprensa Nacional, 11, 234-265.

Perelman, C. (1992). Lógica formal e lógica informal. Caderno de Filosofias Argumentação, Retórica, Racionalidades, Coimbra, Associação de Prof.s de Filosofia, 5, $11-20$.

Perelman, C. (1993). O império retórico: retórica e argumentação. Edições ASA. 
Perelman, C., \& Olbrechts-Tyteca, L. (2005). Tratado da argumentação: a nova retórica. Martins Fontes.

Plantin, C. (2008). A Argumentação: História, teorias, perspectivas. Trad. Marcos Marcionilo. Parábola.

Rossetti, J. P. (2016). Introdução à economia. 21 ed. Atlas.

Reis, D. C. (2010). Identificação da antracnose em palmeira juçara (Euterpe edulis mart.), no litoral norte do estado de São Paulo. (Trabalho de Conclusão de Curso). Instituto de Florestas da Universidade Federal Rural do Rio de Janeiro, Seropédica, RJ.

Reis, P. G. R., \& Galvão, C. (2004). Socio-scientific controversies and students' conceptions about scientists. International Journal of Science Education, London, 26(13), 1621-1633. https://doi.org/10.1080/0950069042000205413

Reis, P. G. R., \& Galvão, C. (2009). Teaching Controversial Socio-Scientific Issues in Biology and Geology Classes: A Case Study. Electronic Journal of Science Education, 13(1), p. 1-24.

Ruppenthal, R. (2017). A habilidade argumentativa e a capacidade de resolver problemas nos anos finais do ensino fundamental. (Tese) Programa de Pós-Graduação em Educação em Ciências: Química da Vida e Saúde, da Universidade de Santa Maria, RS.

Sá, L. P., \& Queiroz, S. L. (2010). Estudo de casos no Ensino de Química. Editora Átomo.

Sá, L. P. (2006). A argumentação no ensino superior de Química: investigando uma atividade fundamentada em estudos de caso. (Dissertação de Mestrado) Instituto de São Carlos da Universidade Federal de São Carlos, SP.

Sá, L. P. (2010). Estudo de casos na promoção da Argumentação sobre questões sóciocientíficas no Ensino Superior de Química. (Tese) Programa de Pós-Graduação da Universidade Federal de São Carlos, SC.

Silva, C. C., \& Gastal, M, L. (2011). Ensinando ciências e ensinando à respeito das ciências. In A. C. Pavão, \& D. Freitas (Orgs.), Quanta ciência há no ensino de Ciências? (pp. 35-44). EdUFSCar.

Silva Junior, G. A. (2019). Elementos de exploração argumentativa docente na sala de aula: uma proposta de análise à luz da teoria de Perelman e Olbrechts-Tyteca. (Tese de doutorado). Programa de Pós-Graduação em Ensino de Ciências e Matemática da Universidade Federal de Natal, RN.

Sousa, T., B. (2017). Técnicas argumentativas através da aprendizagem baseada em problema em um curso de férias. (Dissertação de Mestrado) Programa de Pós-Graduação em Educação em Ciências e Matemáticas da Universidade Federal do Pará, PA.

Toulmin, S. E. (2006). Os usos do Argumento. 2 ed. Martins Fontes. 
Vasconcelos, M. J. V., Carneiro, A. A., \& Valiciente, F. H. (2011). In A. Borém, G. D. Almeida (Orgs.), Plantas Geneticamente Modificadas: Desafios e oportunidades para regiões tropicais (pp. 311-332). Suprema.

Vinhas, B. F., \& Pereira, G. F. S. (2016). Alimentos transgênicos na sala de aula: Considerações para o ensino de Ciências Naturais. Verlag Editora.

Zdziarski, I., Edwards, J. W., Carman, J. A., \& Haynes J. I. (2014). GM crops and the rat digestive tract: A critical review. Environment International, 73(2014), 423-433. http:// dx.doi.org/10.1016/j.envint.2014.08.018

\author{
Gerlany de Fátima dos Santos Pereira \\ (10) https://orcid.org/0000-0002-5503-3737 \\ Universidade do Estado do Amapá \\ Macapá, Amapá, Brasil \\ gerlany.ueap@gmail.com \\ José Messildo Viana Nunes \\ (1) https://orcid.org/0000-0001-9492-4914 \\ Universidade Federal do Pará \\ Belém, Pará, Brasil \\ messildo@ufpa.br \\ Nadia Magalhães da Silva Freitas \\ (1) https://orcid.org/0000-0003-0042-8640 \\ Universidade Federal do Pará \\ Belém, Pará, Brasil \\ nadiamsf@yahoo.com.br
}

Submetido em 04 de fevereiro de 2020 Aceito em 29 de junho de 2020 Publicado em 31 de julho de 2020 